\title{
ORTHOTOPIC NEOBLADDER IN WOMEN. EVALUATION OF OUR EXPERIENCE
}

\author{
NEOVESCICA ORTOTOPICA \\ NELLA DONNA VALUTAZIONE \\ DELLA NOSTRA ESPERIENZA
}

\author{
M. SIMONAZZI, N. SEBASTIO, S. MELI, E. FERRI, P. CORTELLINI \\ UROLOGY DEPARTMENT \\ AZIENDA OSPEDALIERA DI PARMA \\ Chief: prof. P. Cortellini \\ Key words: orthotopic neobladder in women \\ Parole chiave: neovescica ortotopica nella donna
}

SUMMARY: We evaluated the results obtained in radical cystectomy operations with an orthotopic neobladder, performed on 8 female subjects, at our Department since 1996. The aim of this study was to broaden the indication for this surgical treatment to women as well as in men and not only for oncological pathologies.

RIASSUNTO: Abbiamo valutato i risultati ottenuti negli interventi di cistectomia radicale con confezionamento di neovescica ortotopica, eseguiti, su otto soggetti di sesso femminile, presso la nostra Divisione dal 1996. Questo allo scopo di poter ampliare l'indicazione a tale trattamento chirurgico non solo negli uomini e non solo per Ipatologia oncologica. 


\section{INTRODUCTION}

Today the orthotopic neobladder after radical cystectomy can be made for women as well as for men.

An orthotopic ileal reservoir, which allows for micturition through the urethra, represents real progress in reconstructive urological surgery in accurately chosen women who have non neoplastic pathologies.

For a long time orthotopic reconstruction in women was considered not indicated for two main reasons: 1) doubts about the possibility of preserving continence if the bladder neck were removed and 2) the concern regarding poor oncological radicalness.

Recent studies have seen that the bladder neck is not essential for continence, which is mainly ensured by the external urethral sphincter with its voluntary striated muscular component, localized in the median third of the urethra.

\section{MATERIALS AND METHODS}

At our Department, we perform radical cystectomy with Padovan ileal neobladder on women as well as men.

The cases include 8 women aged between 32 and 64 years (mean age 56 years); 6 had T2 and T3 urothelial neoplasia; one had a sarcoma and one had an encrusted cystitis with a very low compliance bladder.

We excluded all the patients with bladder neck neoplasias or involving the trigonum.

In no case was neoadjuvant chemotherapy or radiotherapy used.

\section{INTRODUZIONE}

La neovescica ortotopica nella donna dopo cistectomia radicale può essere realizzata in pazienti di ambo i sessi.

Un reservoir ileale ortotopico, che consenta una minzione per urethram, rappresenta un reale avanzamento della chirurgia urologica ricostruttiva in donne accuratamente selezionate e affette da patologie non neoplastiche.

Nella donna la ricostruzione ortotopica è stata a lungo ritenuta non indicata per due ragioni principali 1) dubbi sulla possibilità di preservare la continenza se il collo vescicale veniva asportato e 2) la preoccupazione di scarsa radicalità oncologica.

Studi recenti hanno dimostrato che il collo vescicale non è determinante per la continenza, assicurata principalmente dallo sfintere uretrale esterno con la sua componente muscolare striata volontaria localizzata nel terzo medio dell'uretra.

\section{MATERIALI E METODI}

Presso la nostra Divisione, eseguiamo interventi di cistectomia radicale con confezionamento di neovescica ileale padovana (V.I.P.), anche su soggetti di sesso femminile.

La casistica consta di otto donne di età compresa tra 32 e 64 anni (età media 56 anni); sei affette da neoplasia uroteliale T2 e T3; una da sarcoma ed una da cistite incrostata con vescica a bassissima compliance. Abbiamo escluso tutte le pazienti con localizzazioni neoplastiche a livello del collo vescicale e del trigono. In nessun caso è stato utilizzato trattamento chemio o radioterapico neoadiuvante. 
Table 1

\section{FOLLOW UP}

- Clinical control

- Oncologic control

\section{- 3 months}

Chest X-ray, Renal U. Sonography, Renal \& Hepatic fuctional blood tests, Sedimentation rate

- 6 months and 1 year

Repeat previous controls

CAT scan addomen and pelvis

- Urodynamics

- Every 3 months

- Video U.D.

- Valsalva LPP

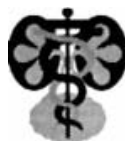

\section{Table 2}

\section{RESULTS}

- Follow up 45-7 months (median 18 months)

- No relapses in 6 pts wih urothelial carcinoma

- 1 pt died after 16 months (sarcoma)

- 3 incomplete bladder emptying

- no pts affected by SUI or VU refluxes

- renal \&metabolic parameters result normal

\section{Table 3}

\section{LITERATURE}

- HAUTMANN (Germany) 25

- SKINNER (Los Angeles) 14

- GHONEIM (Egypt) 32

- STUDER (Cambridge) 15

- HEMAL (New Delhi) 3

- REGGIANI (Bologna) 10

- BERCOVICH (Sassari) 5

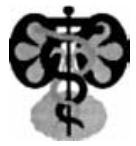




\section{RESULTS}

The 6 patients with urothelial type neoplasia are still today free of recurrences and problems concerning stenosis or vesicoureteral refluxes. They are undergoing a rigid oncological and urodynamic followup (Table 1).

The patient with a sarcoma underwent adjuvant chemotherapy and died from cerebral metastasis six months after the operation (Table 2).

In three cases intermittent catheterization was the procedure adopted for persistence of significative urine retention (above $100 \mathrm{ml}$ ). All the patients had good daytime continence but there is disturbing nocturnal urinary incontinence, solved with selfcatheterization or with two occasions of programmed micturition.

No metabolic complications worth correcting were observed.

\section{DISCUSSION}

The micturition complications of the neobladder in women are connected to the excessive capacity of the reservoir which is supposed to increase temporarily and this is the main factor that limits emptying. In functional terms, both the use of excessively long ileal tracts (more than $40 \mathrm{~cm}$ ) and the lack of respect of the micturition ways and times by the patient, who should always be suitably motivated and informed about the new management of her micturition, may play a negative role. In any case there may be other causes of failure: the possible denervation of the smooth urethral musculature during surgery or the onset of a pouchecele because of the dorsal caudal collapse of the

\section{RISULTATI}

Le sei pazienti con neoplasia di tipo uroteliale sono a tutt'oggi libere da recidive e da problemi riguardanti stenosi o reflussi vescico ureterali. Sono sottoposte a rigido follow up oncologico e urodinamico. (Tab. $n^{\circ} 1$ )

La paziente affetta da sarcoma è stata sottoposta a chemioterapia adiuvante ed è deceduta per metastasi cerebrali a sei mesi dall'intervento. (Tab. $n^{\circ} 2$ )

In tre casi il cateterismo intermittente è stata la procedura adottata per la persistenza di ritenzione d'urina significativa (superiore a $100 \mathrm{ml}$ ). Tutte le pazienti hanno una buona continenza diurna ma è presente una fastidiosa incontinenza urinaria notturna, risolta con autocateterismo o con due minzioni programmate.

Non sono state evidenziate complicanze metaboliche meritevoli di correzione.

\section{DISCUSSIONE}

Le complicanze minzionali della neovescica nella donna sono legate all'eccessiva capacità del serbatoio e questo è il principale fattore limitante allo svuotamento. In tal senso possono giocare un ruolo negativo ai fini funzionali sia l'impiego di tratti ileali eccessivamente lunghi (maggiori di $40 \mathrm{~cm}$.) che il mancato rispetto dei modi e dei tempi minzionali da parte della paziente anche se debitamente motivata ed adeguatamente allertata sulla propria nuova gestione minzionale. Possono esservi comunque altre cause di insuccesso: la denervazione della muscolatura liscia uretrale in fase di dissezione chirurgica o l'insorgenza di un pouchcele per crollo dorso caudale della neovescica rispetto all'anastomosi 
neobladder with respect to the ileourethral anastomosis. In order to avoid this event some authors stressed the need to apply anchorage points from the vagina to the Cooper ligament or, alternatively, to place an omental flap between the neobladder and the vaginal stump as a posterior support.

Some authors maintain that the only way to ensure continence is the correct treatment of the urethra.

It should be manipulated as little as possible and sectioned cleanly, avoiding the dissection below the pubourethral ligaments, which should be respected.

This is made easier by the fact that the dorsal venal complex is much less developed in the woman than in men. Another crucial point is urethra nerve sparing during cystectomy.

The surgical procedure has to be particularly cautious at the posteriorlateral site, that is in the critical area of the fibers of the pelvic plexus. sparing them, is in theory an advantage for continence.

Our encouraging results, of few cases, but in line with the foreign authors who perform this operation (Table 3 ), confirm the feasibility of an orthotopic ileal neobladder in women although more studies and a longer follow-up are necessary.

A larger number of cases could take advantage of wider indications for this kind of reconstruction, not only in oncology but also for other pathologies.

CONCLUSIONS

An accurate selection of the ileo-uretrale. Al fine di ovviare a questa evenienza era stata da alcuni enfatizzata la necessità di applicare punti di ancoraggio dalle pareti vaginali al legamento di Cooper o, in alternativa, di interporre un lembo omentale tra la neovescica ed il moncone vaginale come supporto posteriore.

Alcuni autori sostengono che l'unico momento fondamentale per assicurare la continenza è il corretto trattamento dell'uretra. Questa va manipolata il meno possibile, sezionata in modo netto, evitando la dissezione a valle dei legamenti pubo uretrali, che devono essere rispettati. Del resto ciò è reso più agevole dal fatto che il complesso venoso dorsale è nella donna assai meno sviluppato che nell'uomo. Altro punto cruciale è la "urethra nerve sparing" in corso di cistectomia. A questo fine, particolarmente cauta deve essere la procedura chirurgica in sede postero-laterale e cioè nell'area critica sede delle fibre del plesso pelvico, il cui risparmio rappresenta teoricamente un vantaggio ai fini della continenza.

I nostri incoraggianti risultati seppur numericamente bassi, ma in linea con gli Autori stranieri che si occupano di tale intervento (Tab. $n^{\circ} 3$ ), confermano la fattibilità nella donna di una neovescica ileale ortotopica sebbene siano necessarie casistiche più numerose ed un follow up più lungo. L'incremento numerico dei trattamenti chirurgici potrà avvalersi di indicazioni più ampie per questo tipo di ricostruzione, non solo in campo oncologico ma anche per altre patologie.

\section{CONCLUSIONI}

Un'accurata selezione delle can- 
candidates requires the exclusion of cases, as already in men, with neoplasias at the bladder neck and this is even more necessary for obvious anatomical reasons.

There are three fundamental aspects to bear in mind in the strategy of the reconstruction of the orthotopic bladder:

1) precise knowledge of all the continence and retention mechanisms, as well as of the exact physiopathologic condition of the selected cases;

2) respect of the oncological radicalness;

3) observing and being aware of the functional differences of the continent pouches between men and women.

It should be underlined that this surgery requires complete collaboration between the patient, surgeon and suitable hospital, which should be able to guarantee optimum psychological and clinical assistance. didate richiede l'esclusione dei casi, come già nell'uomo, con localizzazioni neoplastiche a livello del collo vescicale e questo a maggior ragione per ovvî motivi anatomici.

Nella strategia della ricostruzione vescicale ortotopica nella donna vi sono tre momenti fondamentali da tener presente:

1) le precise conoscenze di tutti i meccanismi di continenza e ritenzione, nonché l'esatto inquadramento fisiopatologico dei casi selezionati;

2) il rispetto della radicalità oncologica;

3)I'osservanza e la consapevolezza delle differenze funzionali delle pouche continenti tra uomo e donna.

Va sottolineato come questa chirurgia necessiti di completa collaborazione fra paziente, chirurgo e struttura ospedaliera idonea, in grado di garantire una gestione ottimale psico-assistenziale. 


\section{Marta Simonazzi}

Divisione di Urologia - Azienda Ospedaliera di Parma

Via Gramsci, 14

43100 Parma

Tel. 0521-991182

Fax 0521-991185

\section{REFERENCES / BIBLIOGRAFIA}

1 - ARAI Y; OKUBO K; KONAMI T; KIN S; KANBA T; OKABE T; HAMAGUCHI A; OKADA Y : Voiding function of orthotopic ileal neobladder in women.

Urology 1999 Jul;54(1):44-9

2 - HAUTMANN R.E., PASSS T., KLEINSCHMIDT K., DE PETRICONI R. The ileal neobladder in the female: why it works or not.

J. Urol. 1995; 153: 243A

3 - HAUTMANN R.E., PAISS T., DE PETRICONI R.:

The ileal neobladder in women: 9 years of experience with 18 patients.

J. Urol.1996; 155: 76-81.

4 - PARK JM; MONTIE JE :

Mechanisms of incontinence and retention after orthotopic neobladder diversion. Urology 1998 Apr:51(4):601-9

5 - SHIMOGAKI H; OKADA H; FUJISAWA M; ARAKAWA S; KAWABATA G; KAMIDONO S; YAMANAKA N.

Long-term experience with orthotopic reconstruction of the lower urinary tract in women.

J Urol 1999 Feb; 161(2):573-7

6 - STEIN J P., STENZL A., GROSSFELD G. D., FREEMAN J. A., ESRIG D., et al. : The use of orthotopic neobladders in woman undergoing cystectomy for pelvic malignancy.

World J. Urol., 1996; 14:9-14.

7 - STENZL A., DRAXL H., POSCH B., COLLESELLI K., FALK M., BARTSCH G.:

The risk of urethral tumors in female bladder cancer: can the urethra be used for orthotopic reconstruction of the lower urinary tract?

J. Urol. 1995: 153; 950-955 